\title{
How Can We Predict Success in Poor Responders?
}

Alina Elena BORDEA ${ }^{1,2}$, Elvira BRATILA ${ }^{1,2}$, Diana MIHAI ${ }^{1,2}$, Marina ANTONOVICl ${ }^{3}$, Claudia MEHEDINTU $^{2,3}$, Andreea CARP-VELISCU1,2

\section{Abstract}

Objectives: The aim of this study was to evaluate how can we predict success in poor responder patients in terms of pregnancy rate and live birth rate. Material and method: This study is a review of the newest papers that have in the center the poor responders undergoing treatment involving assisted reproductive techniques (ART). Outcomes: The results show that the most reliable factors when counseling a poor responder patient are age and Anti-Müllerian hormone $(\mathrm{AMH})$ level. Conclusions: The most important factors that influence pregnancy rate are age and ovarian reserve, but other factors such as male pathology and laboratory techniques must be studied deeper.

Keywords: poor responders, $\mathrm{AMH}$, age, pregnancy rate, live birth rate.

\section{Rezumat}

Obiective: Obiectivul studiului este evaluarea mijloacelor prin care putem prezice succesul la pacientele cu răspuns ovarian scăzut la stimularea ovariană controlată din ciclurile de FIV. Material și metodă: Această lucrare este un review al literaturii de specialitate recente. Rezultate: Rezultatele arată că cei mai buni predictori ai ratei de sarcini sunt vârsta și nivelul seric al hormonului anti-Mullerian. Concluzii: Cei mai importanți factori care influențează rata de sarcini sunt vârsta și rezerva ovariană, dar alți factori precum patologia masculină sau tehnicile de laborator ar trebui mai amănunțit studiați.

Cuvinte cheie: pacientele cu răspuns ovarian scăzut, $\mathrm{AMH}$, vârsta, rata de sarcini, natalitatea.

${ }^{1}$ "Prof. Dr. Panait Sârbu" Clinical Hospital of Obstetrics and Gynecology, Bucharest, Romania

${ }_{2}$ "Carol Davila" University of Medicine and Pharmacy, Bucharest, Romania

${ }^{3}$ Department of Obstetrics and Gynecology, „Nicolae Malaxa”

Clinical Hospital, Bucharest, Romania
Corresponding author: Claudia MEHEDINTU, „Carol Davila” University of Medicine and Pharmacy, Bucharest, Romania

E-mail: claudiamehedintu@yahoo.com 


\section{INTRODUCTION}

One of the most frequently addressed questions to the infertility specialist, before a couple decides to use in vitro fertilization (IVF) to conceive, is: "What are the odds of getting pregnant through IVF?". In order to be able to answer this question correctly, many studies have tried to graphically show the real pregnancy rate. Most graphs consider the most important parameters in assessing the chances of obtaining through IVF a pregnancy finalized with an alive newborn, namely: age and ovarian reserve ${ }^{1}$.

If for many causes of infertility there are variants of targeted treatments and therapies, for age and ovarian reserve that decreases with aging, there is still no effective treatment ${ }^{2}$.

In recent years, the birth rate has increased among women over the age of 30 and up to 44 years. Delaying the conception of a child has multiple causes: professional and educational goals, ensuring economic status before birth and so on3.

The POSEIDON (Patient-Oriented Strategies Encompassing Individualized Oocyte Number) group classifies poor prognosis patients with confirmed or expected inappropriate ovarian response to exogenous gonadotropins. The classification takes into consideration 3 main criteria: age, anti-Mullerian hormone $(\mathrm{AMH})$ and the response to a previous controlled ovarian stimulation 4 .

More recent studies show that the measure of success is given by the number of euploid blastocysts we can obtain. At the age of 28, 3 blastocysts are needed to have a $90 \%$ chance that one of them will be euploid ${ }^{5}$. A 2021 study shows that for a 95\% pregnancy rate, 3 euploid blastocysts are needed, independent of the age of the mother6. All true, but the number of euploid blastocysts we can get from a full IVF cycle is age-dependent, as many studies show. The pregnancy rate is also age dependent7.

\section{OVARIAN FOLLICULOGENESIS AND OVARIAN AGING}

Follicular development begins in the fourth month of intrauterine life. Primordial germ cells migrate from the endoderm of the yolk sac to the gonadal ridge, process during which they undergo mitotic divisions. Once reaching the gonadal ridge, the oogonia enter the first stage of meiotic division and become primary oocytes. At 20 weeks of gestation, the number of follicles that form the ovarian reserve is about 7 million. Follicular atresia begins during the intrauterine life and continues until menopause. The number of germ cells decreases to about 2 million at birth, and only 300.000 remain by the time the menarche occurs, meaning that $94 \%$ of the initial follicles disappear by then ${ }^{8}$.

Follicular maturation is classified into 3 stages:

1) The stage of primordial follicles - represents the beginning of follicular development and takes place inside the maternal uterus. At this stage the immature oocytes are surrounded by a single layer of flattened granulosa cells. The follicles do not have vascularization, but feed by diffusion through GAP-type junctions. The transport of steroid precursors is also done by diffusion.

2) The stage of primary follicles - is characterized by the transformation of flattened granulosa cells into cuboidal cells and the increase in the number of cell layers. The diffusion of nutrients and cellular signals received from cells with gonadotropins receptors is also done with the help of GAP junctions. During this stage, the secretion of the pellucid area at the level of the oocyte occurs.

3) The stage of antral follicles - is characterized by the formation of a single antral cavity filled with follicular fluid, between the granulosa cells that form the cumulus oophorus (surrounds the oocyte) and the mural granulosa cells (surrounds the antrum).

Follicular development is considered independent of gonadotropin stimulation until the primary follicle consists of 4 layers of granulosa cells ${ }^{9}$.

The size of the ovarian reserve from the beginning and the percentage of follicles that will become atretic are genetically determined factors. This is also the case for the growth initiation rate. Therefore, the age of climax onset varies from patient to patient and has genetic determinism. Another argument that supports this is that there is a family association regarding the age of menopause for mothers and daughters ${ }^{10}$.

With advancing age, fertility decreases due to follicular exfoliation and oocyte quality. The rate of follicular loss doubles when the number of oocytes falls below 25.000. This happens around the age of $37.5^{11}$.

Menopause is the final step in the ovarian aging process. The follicular decrease with age determines the occurrence of irregular menstrual cycles (due to increased levels of FSH - Follicle-stimulating Hormone) and finally the cessation of menstruation. The parallel 
decrease in oocyte quality contributes to the gradual decline of fertility and ultimately to natural sterility.

FSH is the initiator but also the finisher of folliculogenesis in the human ovary. Significant increases in circulating FSH levels are caused, through negative feedback, by decreased levels of follicular growth factors and follicular differentiation factors related to b-growth transformation factor. AMH is produced by immature ovarian follicles and helps regulate FSH secretion from the pituitary gland. As the number of immature follicles decreases with aging, the negative feedback on FSH decreases and thus the circulating levels of FSH increase. Increased circulating levels of FSH cause improper maturation of granulosa cells of preantral follicles, which have not completed their gonadotropin-independent growth cycle. These follicles will become atretic due to the asynchronous maturation of the somatic and germinal components ${ }^{12}$.

The difference in ovarian aging among women is evident by the difference in age at which menopause occurs. Recognition of women who have low ovarian reserve for their age is extremely relevant for clinical practice. Ovarian reserve assessment tests are relatively accurate in evaluating the response to ovarian stimulation and in evaluating the chances of conceiving through IVF techniques ${ }^{13}$.

\section{INFLUENCE OF AGE ON PREGNANCY RATE}

Age is the main determinant for success in IVF. Fertility decreases naturally with age in both natural and ovarian-stimulated cycles. The decline in fertility begins around the age of 30 and the slope becomes steeper after 35 years. The live birth rate is inversely proportional to the mother's age $\mathrm{e}^{7}$. Moreover, the rate of miscarriage and aborted pregnancies is directly proportional to maternal age, largely due to aneuploidies that increase in frequency with advanced maternal age ${ }^{14}$. Of course, low ovarian reserve is also a factor in predicting pregnancy rates, but even in these cases age is the main determining factor. In other words, women with low ovarian reserve and under the age of 35 have better pregnancy rates than those over this age $\mathrm{e}^{15}$.

Maternal age is the leading cause of embryonic aneuploidy. In other words, the success rate to obtain a euploid blastocyst, able to give a pregnancy and also the implantation rate decrease significantly over the age of 40 years $^{16}$.
The chances of a blastocyst being euploid decrease each year. If the rate of euploid blastocysts is about $60 \%$ in women under 35 , for women aged $40-42$ the rate of euploid blastocysts is a maximum of $30 \%$. In other words, at the age of 28, 3 blastocysts are needed for at least one of them to be euploid ( $90 \%$ probability). For ages 35, 37, 39, 41, 43 and 45, 4, 5, 6, 9, 16 and 29 blastocysts are needed for one to be genetically correct ${ }^{5}$. As mentioned before, the rate of aneuploidy increases significantly after 30 years. The lowest rate of aneuploidy is found in the 26-30 age group ${ }^{17}$. More than $90 \%$ of these imbalances are of maternal origin caused by incorrect chromosomal segregation during oogenesis ${ }^{18}$.

However, predicting the success rate based on ovarian reserve alone is not enough. It is also necessary to correctly assess the ovarian reserve before approximating the chances of obtaining a pregnancy ${ }^{19}$.

\section{INFLUENCE OF OVARIAN RESERVE ON PREGNANCY RATE}

\section{Definition of ovarian reserve}

The concept of ovarian reserve describes a woman's natural endowment and is in close relation with age. The size of the follicular pool in a woman's ovaries between birth and menarche symbolically reflects the starting point of follicular decline. As we already know, most follicles are lost from intrauterine life. The follicle pool varies in size depending on genetically determined factors. If the average number of follicles at birth is around 300,000 per ovary, at the time of menarche this number is significantly lower ${ }^{20}$.

The recruitment rate is also variable: between 100 and up to 7.500 follicles enter the process of maturation and growth each month. The peak is reached around the age of 14 . The number of recruited follicles decreases with age regardless of the initial size of the ovarian reserve $\mathrm{e}^{21,22 \text {. }}$

In other words, fertility decreases with age. This is not only caused by the decrease in the number of follicles, but also by the decline in oocyte quality. The rate of follicular loss becomes 2 times faster when the number of oocytes reaches below 25,000. This happens around the age of 37.5 years ${ }^{11}$.

Therefore, the ovarian reserve is defined as "the number of oocytes left in the ovary". The amount (number) of oocytes left in the ovary (follicular pool) differs from the oocyte quality. The latter reflects "the potential of a fertilized oocyte to give birth" 21 . 
As previously described, the decline in female fertility (decreased ovarian reserve) simultaneous with age is well known. Of course, there can be quite large differences between the ovarian reserve of several women of the same age, as this is genetically determined. In other words, the size of the ovarian reserve and the loss of the ovarian reserve as we age are genetically determined ${ }^{9}$.

\section{Measuring ovarian reserve}

Ovarian reserve assessment tests have become part of standard clinical practice because they can predict ovarian response during controlled ovarian stimulation. They allow patients to be informed about the expectations they should have $\mathrm{e}^{23-25}$.

Measurement of ovarian reserve involves biochemical tests and imaging tests (transvaginal ultrasonography of the ovaries). These markers can estimate the number of oocytes we can extract following controlled ovarian stimulation and ovarian puncture for IVF. When assessed independently of age they are not as effective in predicting reproductive potential ${ }^{26}$.

A large number of studies have investigated the role of the antral follicle count (AFC) in predicting the ovarian response to controlled ovarian stimulation. Thus, the 2019 ESHRE (European Society of Assisted Human Reproduction and Embryology) guideline concluded that predicting the ovarian response to controlled ovarian stimulation based solely on AFC is a reliable marker ${ }^{19}$.

Moreover, the AFC prediction in terms of pregnancy rate is a good one ${ }^{27}$.

FSH is an intensely studied hormone when it comes to assessing ovarian reserve and response to ovarian stimulation treatment. Intracycle variability makes it most commonly measured during the follicular phase. FSH is frequently measured on days 1-4 of the menstrual cycle along with estradiol. An FSH above 10 $\mathrm{mIU} / \mathrm{ml}$ is associated with a low response to controlled ovarian stimulation and low pregnancy rates ${ }^{28}$.

In recent years, $\mathrm{AMH}$ has become the main marker for the evaluation of the ovarian reserve. It is produced by the granulosa cells of the preantral follicles and the small antral follicles. Thus, AMH reflects the exact size of the primordial follicular pool. Among the advantages of using $\mathrm{AMH}$ in the evaluation of the ovarian reserve are:

- it can be measured at any time during the menstrual cycle;

- it correlates well with the number of oocytes we can obtain from controlled ovarian stimulation;
- it correlates well with the rate of clinical pregnancies ${ }^{29,30}$.

Tests to determine serum AMH levels have evolved from manual methods to more robust and automated methods. They have good analytical performance, including improved accuracy and a limit of quantification $\leq 0.08 \mathrm{ng} / \mathrm{ml}^{31}$.

To predict a poor response $(\leq 4$ oocytes collected after controlled ovarian stimulation), the cutoff value of the AMH level of $0.93 \mathrm{ng} / \mathrm{ml}$ was associated with sensitivity, specificity, positive predictive value and negative predictive value of $63.5 \%, 89.2 \%, 52.2 \%$, respectively $92.9 \%{ }^{29}$.

The data from the literature are contradictory when we talk about the correlation of AMH with the live birth rate $\mathrm{r}^{27,32}$.

In patients with low ovarian reserve, $\mathrm{AMH}$ correlates with the age-specific rate of clinical pregnancies. When we take into account both age and ovarian reserve in patients with low ovarian reserve, the prediction of the clinical pregnancy rate is much better ${ }^{33}$.

In patients with low ovarian reserve, $\mathrm{AMH}$ $\leq 1.05 \mathrm{ng} / \mathrm{ml}$ is associated with low live birth rates, in contrast, patients with $\mathrm{AMH} \geq 1.06$ $\mathrm{ng} / \mathrm{ml}$ have much higher live birth rates. In patients under 35 who undergo an IVF procedure, serum AMH levels are an independent predictor of pregnancy rate ${ }^{34}$.

Ovarian reserve assessment markers do not predict the likelihood of pregnancy during sperm insemination from the donor in unstimulated cycles. AMH does not predict pregnancy rate after ovarian stimulation and intrauterine insemination ${ }^{35}$. Although positively correlated with each other and with IVF results, $\mathrm{AMH}$ and AFC can be discordant up to $30 \%$ of the time, as shown by Li H.W. et al. (2014) in his research ${ }^{36}$.

The ESHRE Guide postulates the following ${ }^{19}$ :

1. The prediction of the ovarian response by the value of AMH is reliable.

2. The prediction of the ovarian response by baseline FSH and no other ovarian reserve assessment marker is uncertain.

3. The prediction of the ovarian response by Inhibin $\mathrm{B}$ without another ovarian reserve assessment marker is uncertain.

4. The prediction of the ovarian response by estradiol value without another ovarian reserve assessment marker is uncertain.

The ESHRE guide recommends the use of AFC or $\mathrm{AMH}$ to the detriment of other tests when we need 
to predict the response to controlled ovarian stimulation $^{19}$.

$\mathrm{AMH}$ and $\mathrm{AFC}$ are important means of predicting the chances of success, but there are other variables that should not be neglected and that play a major role in the end result, namely: age, sperm quality (male pathology), genetic quality of embryos, stimulation protocols, laboratory procedures and techniques, embryo transfer technique ${ }^{6,37,38}$.

\section{CONCLUSIONS}

Giving that fertility naturally decreases with age in both natural and ovarian-stimulated cycles, the decline starting around the age of 30 with a steeper slope after 35 years, and that nowadays women tend to delay procreation due to the prioritization of their career and financial status consolidation, ART are more and more used and infertility specialists try more often to bend the natural boundaries of fertility.

\section{References:}

1. Sunkara SK, Rittenberg V, Raine-Fenning N, Bhattacharya S, Zamora J, Coomarasamy A, Association between the number of eggs and live birth in IVF treatment: an analysis of 400135 treatment cycless, Hum Reprod. 2011

2. Andreea Carp-Veliscu and Bogdan Marinescu, Noțiuni de Reproducere Umană Asitată, Editura Medicala Universitara Craiova, 2019

3. Martin JA, Hamilton BE, Osterman MJ, Driscoll AK, Mathews TJ. Births: Final data for 2015. Natl Vital Stat Rep 2017;66:1.

4. Poseidon Group (Patient-Oriented Strategies Encompassing IndividualizeD Oocyte Number) Alviggi $C$, Andersen $C Y$, Buehler K, Conforti A, De Placido G et al. A new more detailed stratification of low responders to ovarian stimulation: from a poor ovarian response to a low prognosis concept. Fertil Steril. 2016;105(6):1452-1453.

5. Esteves SC, Carvalho JF, Martinhago CD, Melo AA, Bento FC, Humaidan P, Alviggi C, POSEIDON (Patient-Oriented Strategies Encompassing IndividualizeD Oocyte Number) Group, Estimation of age-dependent decrease in blastocyst euploidy by next generation sequencing: development of a novel prediction model, Panminerva Med. 2018 Jun 28.

6. Paul Pirtea et al. Rate of true recurrent implantation failure is low: results of three successive frozen euploid single embryo transfers. Fertil Steril 2021 Jan;115(1):45-53.

7. Wendy Y. Zhang et al. Pregnancy and birth outcomes associated with maternal age and euploid embryo grade after natural cycle frozen transfer, Vol 114, Issue 3, Supplement, E305, September 01,2020
Although AMH has become the main marker for the evaluation of the ovarian reserve and is positively correlated with AFC and IVF results, it cannot predict pregnancy rate after ovarian stimulation and intrauterine insemination. Variables that should not be neglected and that play a major role in the end result are sperm quality, genetic quality of embryos, stimulation protocols, laboratory procedures and techniques, embryo transfer technique and further research is needed to evaluate how these variables influence pregnancy rate in poor responders.

Compliance with ethics requirements: The authors declare no conflict of interest regarding this article. The authors declare that all the procedures and experiments of this study respect the ethical standards in the Helsinki Declaration of 1975, as revised in 2008(5) and the national law. Informed consent was obtained from the patient described in the clinical case and his parents.

8. Daniel Grigore, Endocrinologie clinică, Ed. Univ. Carol Davila, București, 2008

9. Williams Ginecologie, ediția a II-a, Hoffman et al. - Radu Vlădăreanu, coordonatorul ediției în limba română, București, 2014, 2, 414

10. Torgerson DJ, Thomas RE, Reid DM. Mothers and daughters menopausal ages: is there a link? Eur J Obstet Gynecol Reprod Biol. 1997

11. te Velde ER, Scheffer GJ, Dorland M, Broekmans FJ, Fauser BC: Developmental and endocrine aspects of normal ovarian aging. Mol Cell Endocrinol 1998, 145:67-73.

12. Beemsterboer SN, Homburg R, Gorter NA, Schats R, Hompes PG, Lambalk CB: The paradox of declining fertility but increasing twinning rates with advancing maternal age. Hum Reprod 2006, 21:1531-1532

13. Broekmans, F. J., Soules, M. R., \& Fauser, B. C. (2009). Ovarian Aging: Mechanisms and Clinical Consequences. Endocrine Reviews, 30(5), 465-493. doi:10.1210/er.2009-0006

14. Chan-Wei Jia et al. Aneuploidy in Early Miscarriage and its Related Factors, Chin Med J (Engl). 2015 Oct 20; 128(20): 2772-2776.

15. Coccacia M.E. and Rizzello F. Ovarian reserve. Ann NY Acad Sci. 2008; 1127: 27-30.

16. Hassold T, Hall H, Hunt P. The origin of human aneuploidy: where we have been, where we are going. Hum Mol Genet (2007).

17. Franasiak, J. M., Forman, E. J., Hong, K. H., Werner, M. D., Upham, K. M., Treff, N. R., \& Scott, R. T. (2014). The nature of aneuploidy with increasing age of the female partner: a review of 15,169 consecutive trophectoderm biopsies evaluated with comprehensive 
chromosomal screening. Fertility and Sterility, 101(3), 656-663. e1. doi:10.1016/j.fertnstert.2013.11.004.

18. Nagaoka SI, Hassold TJ, Hunt PA. Human aneuploidy: mechanisms and new insights into an age-old problem. Nat Rev Genet (2012).

19. ESHRE Reproductive Endocrinology Guideline Group. OVARIAN STIMULATION FOR IVF/ICSI - Guideline of the European Society of Human Reproduction and Embryology. OCTOBER 2019.

20. Sills, E. S., Alper, M. M., \& Walsh, A. P. H. (2009). Ovarian reserve screening in infertility: Practical applications and theoretical directions for research. European Journal of Obstetrics \& Gynecology and Reproductive Biology.

21. Hansen KR, Knowlton NS, Thyer AC, Charleston JS, Soules MR, Klein NA. A new model of reproductive aging: the decline in ovarian non-growing follicle number from birth to menopause. Hum Reprod. 2008;23(3):699-708. doi: 10.1093/humrep/dem408.

22. Wallace WH, Kelsey TW. Human ovarian reserve from conception to the menopause. PLoS One. 2010;5(1):e8772. doi: 10.1371/ journal.pone.0008772.

23. Broer, S.L., Dólleman, M., Opmeer, B.C., Fauser, B.C., Mol, B.W., and Broekmans, F.J.M. AMH and AFC as predictors of excessive response in controlled ovarian hyperstimulation: a meta-analysis. Hum Reprod Update. 2011; 17: 46-54.

24. Dewailly D. and Laven J. AMH as the primary marker for fertility. Eur J Endocrinol. 2019; 181: D45-D51.

25. Tal R.and Seifer D.B. Ovarian reserve testing: a user's guide. Am J Obstet Gynecol. 2017; 217: 129-140.

26. Fanchin R.et al. High reproducibility of serum anti-müllerian hormone measurements suggests a multi-staged follicular secretion and strengthens its role in the assessment of ovarian follicular status. Hum Reprod. 2005; 20: 923-927.

27. Sara S E Alson et al, Anti-müllerian hormone levels are associated with live birth rates in ART, but the predictive ability of anti-müllerian hormone is modest, Eur J Obstet Gynecol Reprod Biol. 2018 Jun;225:199-204.

28. Broekmans F et al. A systematic review of tests predicting ovarian reserve and IVF outcome. Hum Reprod Update. 2006; 12: 685718.
29. Baker, Valerie L. et al. Validation study of the Access antimüllerian hormone assay for the prediction of poor ovarian response to controlled ovarian stimulation. Fertility and Sterility, 2021.Volume 116 , Issue 2, $575-582$.

30. Hale Bayram et al, Anti-Müllerian hormone as a predictor of pregnancy in women under 35 years with unexplained infertility undergoing ICSI: a retrospective study, Minerva Obstet Gynecol. 2021 Apr 27.

31. Pearson K.et al Assessment of the Access AMH assay as an automated, high-performance replacement for the AMH Generation II manual ELISA. Reprod Biol Endocrinol. 2016; 14:8

32. [32] Gayathree Murugappan et al, Antimullerian hormone is a predictor of live birth in patients with recurrent pregnancy loss, Fertil Res Pract. 2019 Mar 15;5:2.

33. [33] Norbert Gleicher, M.D. et al. Anti-Müllerian hormone (AMH) defines, independent of age, low versus good live-birth chances in women with severely diminished ovarian reserve. VOLUME 94, ISSUE 7, P2824-2827, DECEMBER 01, 2010.

34. Papri Sarkar, Prognostic value of low anti-mullerian hormone level during IVF among women: a SART CORS Study, VOLUME 114, ISSUE 3, SUPPLEMENT, E454, SEPTEMBER 01, 2020.

35. Hansen K.R. et al.Predictors of pregnancy and live-birth in couples with unexplained infertility after ovarian stimulation-intrauterine insemination. Fertil Steril. 2016; 105: 1575-1583.

36. Li H.W. et al. Ovarian response and cumulative live birth rate of women undergoing in-vitro fertilisation who had discordant anti-müllerian hormone and antral follicle count measurements: a retrospective study. PLoS One. 2014; 9e108493.

37. Ashok Agarwal et al, Sperm DNA Fragmentation: A New Guideline for Clinicians, World J Mens Health. 2020 Oct; 38(4): 412-471.

38. Practice Committee of the American Society for Reproductive Medicine, Comparison of pregnancy rates for poor responders using IVF with mild ovarian stimulation versus conventional IVF: a guideline, Fertil Steril. 2018 Jun;109(6):993-999. 